\title{
Impacts of artificial light at night on sleep: a review and prospectus
}

Anne E. Aulsebrook ${ }^{1 *}$, Therésa M. Jones ${ }^{1}$, Raoul A. Mulder ${ }^{1}$ and John A. Lesku ${ }^{2}$

a

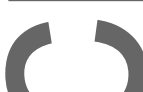

${ }^{1}$ The University of Melbourne, School of BioSciences, Melbourne, Victoria 3010, Australia

${ }^{2}$ La Trobe University, School of Life Sciences, Melbourne, Victoria 3086, Australia

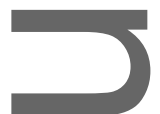

Total number of text figures, graphs and charts: 0

Abbreviated title: Impacts of artificial light at night on sleep

* Correspondence to: Anne Aulsebrook at:

Post: The University of Melbourne, School of BioSciences, Parkville, VIC 3010, Australia

Telephone:+61430733930

Email: aulsebrooka@gmail.com

Supporting grant information: Hermon Slade Foundation to Jones (HSF 14/4)

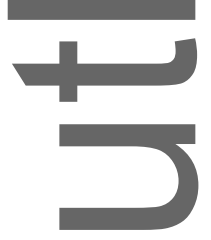

This is the and mascript accepted for publication and has undergone full peer review but has not been thr on th copyediting, typesetting, pagination and proofreading process, which may lead to differences betw this version and the Version of Record. Please cite this article as doi: 10.1002/jez.2189.

This article is protected by copyright. All rights reserved. 


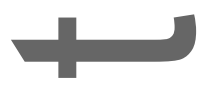

Natural cycles of light and darkness govern the timing of most aspects of animal behaviour and physiology: Artificial light at night (ALAN) - a recent and pervasive form of pollution - can mask natural photoperiodic cues and interfere with biological rhythms. One such rhythm vulnerable to perturbation is the sleep-wake cycle. ALAN may greatly influence sleep in humans and wildlife, particularly in animals that sleep predominantly at night. There has been some recent evidence for impacts of ALAN on sleep, but critical questions remain. Some of these can be addressed by adopting approaches already entrenched in sleep research. In this paper, we review the current evidence for impacts of ALAN on sleep, highlight gaps in our understanding, and suggest opportunities for future research.

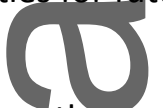

Keywords: anthropogenic light, ALAN, circadian rhythms, electroencephalogram, pollution, urbanization

\section{Research Highlights}

Artificial light at night can have profound impacts on sleep. We review the evidence for these impacts and provide a prospectus for future research.

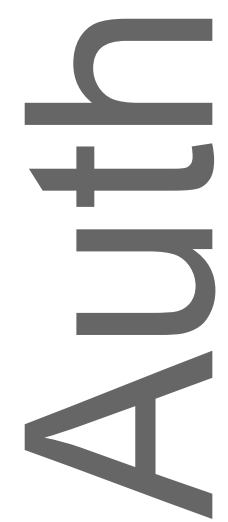

This article is protected by copyright. All rights reserved. 


\section{Introduction}

Endogenous daily (or circadian) rhythms underpin almost all biological processes and are critical for maximizing fitness (Aschoff, 1989, DeCoursey, Walker, \& Smith, 2000, Greives et al., 2015). Circadian rhythms evolved under a predictable, 24-hour cycle of light and darkness, and allow organisms to synchronise their biology with predictable daily changes in their environment (Aschoff, 1989, Kronfeld-Schor, Visser, Salis, \& van Gils, 2017). Coordination with the environment is achieved via environmental cues, called zeitgebers, which entrain or synchronise the internal pacemaker system (Aschoff, 1965). The most important zeitgeber is light (Aschoff, 1989, Berson, Dunn, \& Takao, 2002, Czeisler et al., 1986, Panda, Hogenesch, \& Kay, 2002). Loss or disruption of circadian rhythms, and the subsequent de-synchronization of physiological processes, can have detrimental outcomes for health (Alibhai, Tsimakouridze, Reitz, Pyle, \& Martino, 2015, Martino et al., 2008) and survival (DeCoursey et al., 2000).

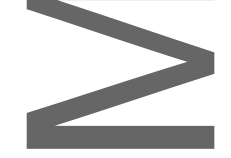

In animals, the sleep-wake cycle is arguably the most conspicuous, ubiquitous, and important circadian rhythm. All animals - even simple animals, including jellyfish (Nath et al., 2017) and flatworms (Omond et al., 2017) - sleep. Sleep can have important benefits for development and learning (Derégnaucourt, Mitra, Fehér, Pytte, \& Tchernichovski, 2005, Kayser, Yue, \& Sehgal, 2014), attention, motivation and emotional reactivity (Van Dongen, Maislin, Mullington, \& Dinges, 2003), (a) hand-eye coordination (Dawson \& Reid, 1997), memory (Diekelmann \& Born, 2010), immune function (Imeri \& Opp, 2009), neurological waste clearance (Xie et al., 2013), and energy homeostasis (Schmidt, 2014, Schmidt, Swang, Hamilton, \& Best, 2017). However, sleep also This article is protected by copyright. All rights reserved. 
precludes other vital activities, such as foraging, anti-predator vigilance, and mating (Kronfeld-Schor

\& Dayan, 2003, Lesku et al., 2012, Lima, Rattenborg, Lesku, \& Amlaner, 2005, Roth, Rattenborg, \& Pravosudov, 2010). To balance these requirements, species have evolved diverse patterns of sleep and wakefulness (Lesku, Roth, Amlaner, \& Lima, 2006), shaped by complex interactions with predators, competitors, food availability, and other factors (Acerbi \& Nunn, 2011, Lesku, Roth, Rattenborg, Amlaner, \& Lima, 2009). These daily sleep-wake patterns, whether nocturnal or diurnal, are often regulated, at least in part, by light (Dijk \& Archer, 2009, Fisher, Foster, \& Peirson, 2013).

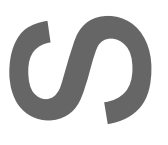

Within the past century, natural light cycles have become distorted by the presence of artificial light at night (ALAN; Gaston, Davies, Nedelec, \& Holt, 2017). Moreover, light pollution has become a rapidly increasing and global phenomenon (Davies \& Smyth, 2018, Falchi et al., 2016, Kyba et al., 2017), prompting concerns about the possible negative impacts of ALAN on sleep in humans (Czeisler, 2013, Erren \& Reiter, 2009, Navara \& Nelson, 2007, Pauley, 2004, Stevens et al., 2007, Stevens \& Zhu, 2015) and wildlife (Dominoni, Borniger, \& Nelson, 2016, Dominoni, Goymann, Helm, \& Partecke, 2013a, Gaston et al., 2017, Randler, 2014). In species that sleep predominantly at night, sleep is particularly likely to be disrupted by ALAN, and there is now evidence that diurnal songbirds exposed to ALAN commence their activity earlier (Da Silva, Samplonius, Schlicht, Valcu, \& Kempenaers, 2014, Da Silva, Valcu, \& Kempenaers, 2016, de Jong et al., 2016, Kempenaers, Borgstrom, Loës, Schlicht, \& Valcu, 2010, Nordt \& Klenke, 2013, Spoelstra, Verhagen, Meijer, \& Visser, 2018; but see Da Silva et al., 2017a) and are active for longer each day (Da Silva, DiezMéndez, \& Kempenaers, 2017b, de Jong et al., 2016, Dominoni, Helm, Lehmann, Dowse, \& Partecke,

This article is protected by copyright. All rights reserved. 
mammals, and fish (approximately $0.3-1$ lux) can also suppress their production of melatonin (Brüning, Hölker, Franke, Preuer, \& Kloas, 2015, Dominoni et al., 2013a, Robert, Lesku, Partecke, \& (1) Chambers, 2015), a hormone that promotes sleep in diurnal species (Gandhi, Mosser, Oikonomou, \& Prober, 2015, Tan et al, 2010).

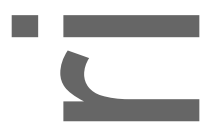

While a connection between ALAN and sleep has been deemed 'intuitive' (Chepesiuk, 2009), research outcomes are often conflicting and our understanding is far from complete. For example, some studies indicate that ALAN reduces sleep duration in humans (Cho et al., 2016, de la Iglesia et al., 2015, Ohayon \& Milesi, 2016), while others show no such effect (Beale et al., 2017, Chang, Aeschbach, Duffy, \& Czeisler, 2014, Cho, Joo, Koo, \& Hong, 2013, Samson et al., 2017b, Wams et al., 2017). Even without affecting the duration of sleep, exposure to ALAN can disrupt the timing and composition of sleep (Beale et al., 2017, Chang et al., 2014, Chellappa et al., 2013, Cho et al., 2016, Cho et al.,2013, Santhi et al., 2012, Wams et al., 2017), but few studies have investigated such impacts in real-world settings (Aulsebrook, Jones, Rattenborg, Roth, \& Lesku, 2016, but see Wams et al., 2017). Furthermore, interspecific variation and methodological differences between studies including different light exposures and methods for measuring sleep - can make results difficult to compare and generalise. Nevertheless, there is mounting evidence from laboratory animals, humans, and wildlife demonstrating impacts of ALAN on sleep. Here, we summarise the existing evidence, focussing mostly on diurnal animals, whose sleep is most likely to be adversely affected by light at night. We then highlight the current gaps in our understanding and provide a prospectus for future research.

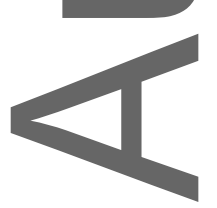

This article is protected by copyright. All rights reserved. 

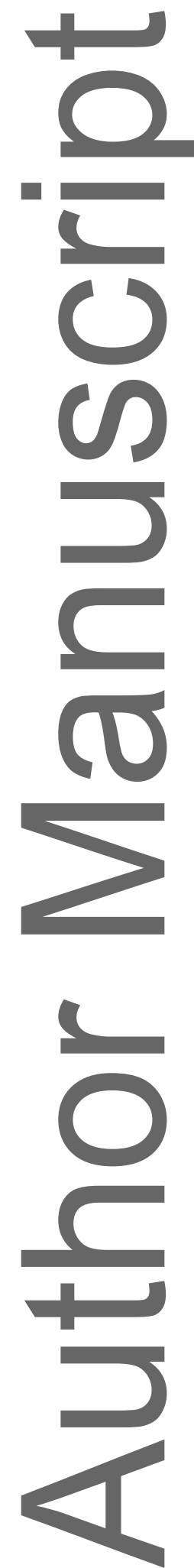

This article is protected by copyright. All rights reserved. 
Laboratory-based sleep studies: mechanisms and physiology

100

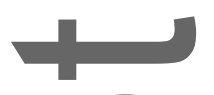

Our understanding of sleep comes primarily from the laboratory, where sleep is easiest to record.

Sleep is typically characterized by a rapidly-reversible, homeostatically-regulated state of reduced (

responsiveness, accompanied by behavioural quiescence, and changes in the electrical activity of the

nervous system (Joiner, 2016). In neuroscientific studies, the 'gold-standard' approach to measuring

sleep is with recordings of electrical activity in the brain, often the electroencephalogram (EEG).

These recordings show that mammals and birds have two main sleep states: rapid-eye movement (REM) and non-REM sleep (Lesku \& Rattenborg, 2014, Vyazovskiy \& Delogu, 2014). Rapid-eye movement sleep is characterised by small, fast waves of electrical activity, while non-REM sleep

110 (referred to as slow wave sleep in non-human animals) is characterised by large, slow brain waves.

The size and incidence of slow waves during non-REM sleep (i.e. low-frequency power density, or 'slow wave activity') is used as a proxy for sleep depth and intensity, as greater slow wave activity is associated with deeper, more intense sleep (Tobler, 2011). Until recently, it was only possible to record brain activity in a laboratory setting, owing to technological constraints in the size of recording equipment (Aulsebrook et al., 2016, Rattenborg et al., 2017).

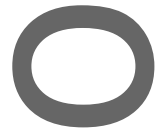

Light can affect sleep in several ways. First, exposure to light entrains sleep's circadian rhythm, primarily bysuppressing the photosensitive pathway of melatonin (Axelrod, Wurtman, \& Snyder, 1965, Berson et al., 2002, Reiter, Tan, \& Fuentes-Broto, 2010). This pathway is most sensitive to short or blue (460-480 nm) wavelengths of light (Berson et al., 2002, Czeisler et al., 1986, Reiter et This article is protected by copyright. All rights reserved. 
al., 2010). Light at night can therefore disrupt circadian rhythms (Dominoni et al., 2016, Stevens \& Zhu, 2015, Yadav, Verma, \& Singh, 2017), which not only shifts the timing of the sleep-wake cycle, but also dampens its rhythm (Dijk \& Archer, 2009, Fisher et al., 2013). Second, exposure to light can have directeffects on sleep and wakefulness, without necessarily affecting circadian rhythms 125 (Altimus et.al., 2008, Cajochen, Zeitzer, Czeisler, \& Dijk, 2000, Chang, Scheer, Czeisler, \& Aeschbach, 2013, Chen et al, 2017, Gandhi et al., 2015, Rattenborg, Obermeyer, Vacha, \& Benca, 2005). Finally, light at night can allow animals that are normally diurnal to extend their activity into the night (e.g. Bakken \& Bakken, 1977, Gaston et al., 2017, Santos et al., 2010, Stracey, Wynn, \& Robinson, 2014; reviewed by Gaston et al., 2017). Thus, there is compelling reason to expect impacts of ALAN on sleep, although the relative contributions of different mechanisms can be difficult to disentangle.

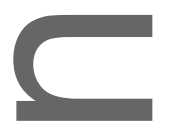

To investigate how exposure to light affects sleep, many studies have used nocturnal rodents as laboratory models. Such studies have typically compared more naturalistic light cycles (12:12 light:dark) with constant light, constant darkness, or exposure to bright daytime light during the usual dark phase (e.g. Benca, Gilliland, \& Obermeyer, 1998, Phillips, Savenkova, \& Karatsoreos, 2015, Stephenson, Lim, Famina, Caron, \& Dowse, 2012, Tobler, Franken, Alföldi, \& Borbély, 1994). In addition, two studies have investigated the effects of more ecologically-relevant 'dim' ALAN on sleep. These studies found no effects of 'dim' ALAN (5 lux) on total sleep duration in rats (Stenvers et al., 2016) or mice (Borniger, Weil, Zhang, \& Nelson, 2013), which is consistent with the idea that may have little or ALAN may have little or no negative effect on sleep in nocturnal animals (Borniger et al., 2013). However, exposure to 'dim' ALAN affected sleep-wake rhythms in rats, causing them to redistribute daytime sleep into the night (Stenvers et al., 2016). Such effects on sleep timing could have This article is protected by copyright. All rights reserved. 
important ecological consequences, including increased competition between diurnal and nocturnal species. Nevertheless, the degree to which observations can be generalised to other contexts is unclear (Calisi \& Bentley, 2009, Horne, 2013). Effects of light exposure can vary even among different rat strains, with albino rats showing different responses to disruptive light cycles than pigmentedrats (Benca et al., 1998). Many strains of laboratory mice are also melatonin-deficient (Kasahara, Abe, Mekada, Yoshiki, \& Kato, 2010), which could influence study outcomes. Importantly, nocturnal rodents are also very limited as a model for how ALAN affects humans and other diurnal species, given that light affects nocturnal and diurnal species in different ways.

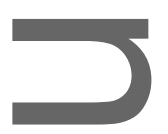

In diurnal species, laboratory studies have typically found effects of ALAN on sleep. In pigeons (Columba livia), continuous exposure to artificial light strongly suppresses or even eliminates sleep (Berger \& Phillips, 1994, Phillips \& Berger, 1992), although the classification of sleep in these studies likely affected the interpretation of the results (Martinez-Gonzalez, Lesku, \& Rattenborg, 2008). Another study of pigeons found that changing from a 12:12 light:dark cycle to a 3:3 cycle also reduced sleep behaviour (defined by eye closure; Rattenborg et al., 2005). However, laboratory research has generally neglected the effects of more realistic ALAN exposures on diurnal species, besides humans. In humans, exposure to artificial light in the evening or throughout the night can variously delay sleep onset (Chang et al., 2014, Santhi et al., 2012; reviewed by Cho et al., 2015), cause more frequent awakenings from sleep (Chellappa et al., 2013, Cho et al., 2013), decrease total sleep duration (Cho et al., 2016) or sleep intensity (Chellappa et al., 2013), and alter the relative proportions of REM and non-REM sleep (Chang et al., 2014, Cho et al., 2016, Cho et al., 2013). Nevertheless, exact outcomes vary between studies. For example, Cho et al. (2013) found no effect This article is protected by copyright. All rights reserved. 
of bright bedside light (40 lux) on total sleep duration, whereas Cho et al. (2016) found that comparatively dim light at night ( 5 or 10 lux) decreased total sleep duration. Similarly, Chang et al. (2014) found that use of a light-emitting e-Reader before bedtime increased the time needed to fall asleep (sleeplatency) and decreased REM sleep, yet Rångtell et al. (2016) observed no effect of eReader use-on sleep.

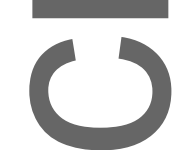

Inconsistent findings could be explained by multiple factors. They may be partly due to small sample sizes, given that many studies have been of fewer than 20 subjects. In addition, the effects of light at night on sleep and alertness can depend on the spectra (Ayaki et al., 2016, Chellappa et al., 2013, Santhi et al. 2012), timing (Carrier \& Dumont, 1995), duration (Chang et al., 2012), and intensity (Cajochen et al., 2000) of the light exposure, as well as prior exposure to light (Chang, Scheer, \& Czeisler, 2011, Chang et al., 2013). It is therefore critically important for studies to report this information to facilitate comparisons between studies and replication of research. Notably, many studies (of humans and other species) fail to provide sufficient spectral information, even though short (blue) wavelengths of light are known to have the greatest impact on melatonin production, circadian rhythms and alertness (Berson et al., 2002, Czeisler et al., 1986). A final consideration is that there are also limitations of recording sleep in the laboratory. Homogenous laboratory lighting may not capture the spatial and temporal heterogeneity of light exposure in urban environments and homes (Gaston, Duffy, Gaston, Bennie, \& Davies, 2014). Furthermore, in the laboratory, an individual's behaviour may be restricted or otherwise influenced by their unusual sleeping environment. To understand the impacts of ALAN, we therefore also need to complement these studies with research in real-world settings (Aulsebrook et al., 2016).

This article is protected by copyright. All rights reserved. 


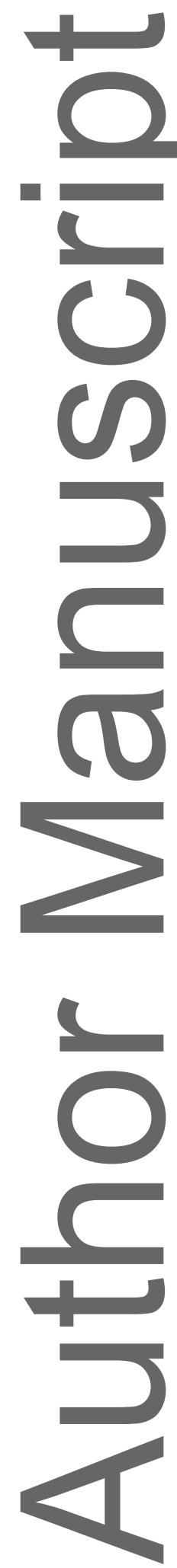

This article is protected by copyright. All rights reserved. 


\section{Human sleep: real-world comparisons}

190

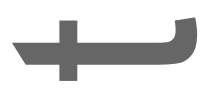

Historical research indicates that prior to the introduction of electric light, human sleep patterns differed from those of today. Instead of sleeping in a single consolidated episode each night

-

(monophasic sleep), people slept in two bouts (biphasic sleep), each of which lasted a few hours with a bout of wakefulness in between (Ekirch, 2001, 2015, 2016). This has led to conjecture that

artificial light has caused an 'unnatural' shift in human sleep, whereby people now stay awake later and condense their sleep into a shorter period. Accordingly, a laboratory study found that people adopted biphasic sleep when exposed to 14 hours of darkness each night (Wehr, 1992). There is also evidence of biphasic sleep in some contemporary communities without electricity (Samson et al., 2017b), but not others (Beale et al., 2017, de la Iglesia et al., 2015, Peixoto, da Silva, Carskadon, \& Louzada, 2009, Samson, Crittenden, Mabulla, Mabulla, \& Nunn, 2017a, Yetish et al., 2015). Despite some dispute about the likely origins of biphasic sleep in humans (Ekirch, 2016, Yetish et al., 2015), sleep in western societies has clearly changed in recent history (Ekirch, 2015). However, since the invention and widespread use of electric light, there have been other social, cultural, and technological changes that are also likely to have affected sleep (e.g. Gradisar et al., 2013). It is therefore difficult to isolate the role of artificial light on sleep from historical records alone.

Cross-sectional and comparative studies provide additional support for impacts of artificial light on sleep. People in communities with access to electricity tend to go to sleep later than those without (Beale et al.,2017, de la Iglesia et al., 2015, Peixoto et al., 2009) and, in some cases, also sleep less

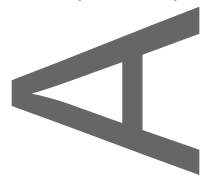

This article is protected by copyright. All rights reserved. 
(de la Iglesia et al., 2015). In the United States, people exposed to higher-intensity outdoor light at night also report delayed bedtimes, later wake-up times, shorter sleep durations, and increased daytime sleepiness (Ohayon \& Milesi, 2016). Similarly, the use of light-emitting technology before sleep is associated with increased sleep latency and decreased sleep duration (Hysing et al., 2015), while exposure to light later in the evening is associated with delayed sleep times and increased awakenings, but no difference in sleep duration (Wams et al., 2017). Such studies are somewhat limited by the methods used to measure sleep; almost all rely on actigraphy or questionnaires (but see Wams et al., 2017). These techniques are valuable, but less accurate and comprehensive than measurements of brain state (Marino et al., 2013, Paquet, Kawinska, \& Carrier, 2007, Westerlund, Lagerros, Kecklund, Axelsson, \& Akerstedt, 2016). Moreover, sleep need builds as a function of prior sleep-wake history and the intensity of brain use during that wakefulness (Huber et al., 2006, Lesku, Vyssotski, Martinez-Gonzalez, Wilzeck, \& Rattenborg, 2011b, Tobler, 2011). If exposure to light at night is associated with different waking experiences, this could have a confounding effect on the timing and duration of sleep. For example, in a study by Beale et al. (2017), people from a rural community without electricity were also doing much more intense physical labour than those in the urban community with electricity. As with historical studies, it is therefore challenging to isolate the effects of ALAN from other factors.

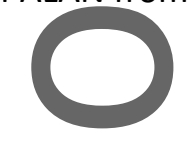

An alternative and powerful approach can be to experimentally manipulate evening or night-time light exposure in people's homes. Very few sleep studies have adopted this approach, presumably due to the combined challenges of recording sleep and adhering to experimental protocols in the home environment. Interestingly, when people "maximised" their home light exposure to 46-82 lux This article is protected by copyright. All rights reserved. 
in the evening, they went to bed only slightly later (average difference 14 minutes) than when they "minimised" their exposure to 1-5 lux and wore short-wavelength-blocking glasses (Burgess \& Molina, 2014). Furthermore, there was no effect on wake time or total sleep duration, despite impacts on circadian timing. Similarly, in a rural community in Madagascar, the use of electric field lanterns for one week had no effect on participants' sleep (Samson et al., 2017b). In another study, researchers took-eight participants camping without electric lights (Wright et al., 2013). After one week of camping, the participants went to sleep earlier on average, and there was less betweenindividual variability in their sleep timing than when they were at home. Of course, as with comparative studies of human sleep, confounding factors such as increased fatigue associated with exercise may have influenced patterns of sleep in this study. Ongoing developments in our ability to record sleep at home, using reasonably cheap and unobtrusive technology (e.g. Winnebeck, Fischer, Leise, \& Roenneberg, 2017), will hopefully facilitate further research. Such research could also help to address the extent to which outdoor illumination affects human sleep, and whether illumination from indoor lighting and light-emitting screens effectively overwhelms effects from external sources of illumination. It is also worth noting that many people are likely aware that light at night can disrupt sleep, and these expectations could influence study outcomes.

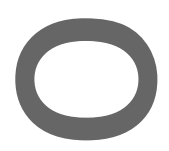

\section{Sleep behaviour in wildlife}

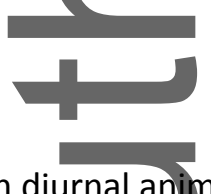

Sleep in diurnal animals is likely to be affected by illumination from streetlights, security lights and other outdoor lighting intended for human security and entertainment. Research has demonstrated This article is protected by copyright. All rights reserved. 
that ecologically-relevant light intensities can affect sleep behaviour in wildlife. These studies have so far been based exclusively on two songbird species: great tits (Parus major) and blue tits (Cyanistes caeruleus). By video-recording wild blue tits inside their nest boxes, Steinmeyer, Schielzeth, Mueller, \& Kempenaers (2010) observed behavioural and postural changes that are thought to be associated with sleep (Amlaner \& Ball, 1983, Stuber, Baumgartner, Dingemanse, Kempenaers, \& Mueller, 2016). Specifically, a bird was considered asleep when it had its beak tucked backwards beneath its scapulars for at least 30 seconds, and awake when it had not assumed that posture for at least 10 seconds. Assuming this to be true, birds woke earlier when exposed to higher intensities of light at night. Subsequent studies used LED lights inside nest boxes to experimentally manipulate light at night, and record the effects on sleep behaviour using the same definition (Raap, Pinxten, \& Eens, 2015, 2016, Sun, Raap, Pinxten, \& Eens, 2017). Interestingly, exposure to light at night decreased the duration of night-time sleep behaviour in great tits, but not blue tits (Sun et al., 2017), and the effects on female great tits were much greater during the nestling period (Raap et al., 2016).

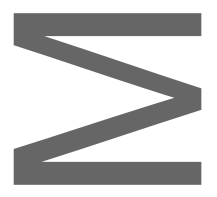

Field-based studies represent a critical first step towards understanding how ALAN affects sleep in wildlife. However, while the resting behaviour of animals is interesting and informative, it is not necessarily a good proxy for sleep (Aulsebrook et al., 2016). Some animals can adopt wake-like postures during sleep (Lesku et al., 2011a, Rattenborg et al., 2016), and others can be awake while in ostensibly sleep-like postures (Voirin et al., 2014). Furthermore, sleep behaviour in great and blue tits has not yet been verified with recordings of brain state, meaning that researchers must make assumptions about sleep onset and continuity. Critically, sleep behaviour alone does not inform us This article is protected by copyright. All rights reserved. 
275 about the impacts of ALAN on sleep composition or intensity. This is particularly important since ALAN can affect these factors without affecting total sleep duration (e.g. Chang et al., 2014, Cho et al., 2013, Stenvers et al., 2016). It is also possible that birds sleep less at night when exposed to ALAN, but compensate by sleeping more intensely, or by napping outside their nest box during the day.
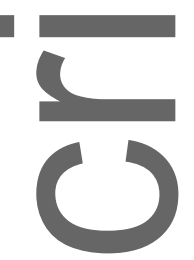

To expand on observations of sleep behaviour, future research will need to adopt other methods for measuring sleep in the wild. Advances in miniaturisation have given rise to data loggers that can record brain activity in wild animals (Lesku et al., 2012, Rattenborg et al., 2016, Rattenborg et al., 2008, Scriba et al., 2013, Vyssotski et al., 2009). Such EEG data loggers are currently only suitable for animals larger than $100 \mathrm{~g}$, which means that they are still too large for use on many songbirds, including blue and great tits, which weigh around $11 \mathrm{~g}$ and $16 \mathrm{~g}$, respectively. However, EEG data loggers could be used in many other study systems, and ongoing miniaturisation of technology is likely to provide further opportunities in the future. Interestingly, the discovery of a biomarker for sleep loss, oxalic acid (Weljie et al., 2015), also shows some promise for determining effects of ALAN on sleep. However, results from two studies in wild great tits are equivocal. Ouyang et al. (2017) found that birds in their 'white light treatment' (roosting up to 160 metres from experimental white LED streetlights) were more active at night than birds in their dark control, red or green light treatments. Greater nocturnal activity was associated with decreasing oxalic acid over the course of the three-month study, potentially reflecting a sleep-deprived condition (but see Raap, Pinxten, \& Eens, 2017). Conversely, Raap, Pinxten, \& Eens (2018) found that exposure to white ALAN inside the nest box caused an unexpected increase in oxalic acid concentrations in male, but not female, This article is protected by copyright. All rights reserved. 
nestlings. Since oxalic acid has so far only been validated as a biomarker for sleep loss in humans and rodents experiencing relatively severe sleep deprivation (Weljie et al., 2015), further validation is required.<smiles>C1C[As]C1</smiles>

The combined evidence from laboratory experiments, correlational field studies, and field experiments suggests that light at night has the capacity to affect most, and perhaps even all aspects of sleep in diurnal species. Nevertheless, there are other critical questions that still need to be addressed. What are the impacts of real-world light exposures on sleep? Are people and wild animals able to ameliorate such impacts, by retreating to darker refuges to sleep at night? How is sleep in other animals, beyond humans, songbirds and laboratory rodents, affected by ALAN? When ALAN disrupts sleep, what are the 'downstream' costs, and how can these be mitigated? Below, we discuss these questions and possible approaches in further detail.

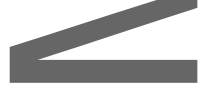

Investigating how ecologically-relevant ALAN affects sleep is fundamental for understanding the scale of its impact. Experimental studies often use light exposures that have unrealistic timing, or that are more intense and spatially homogenous than would be experienced in real-world settings (Santhi et al., 2012). In some studies, light is also presented in an unrealistic manner that might influence sleep via other mechanisms. For example, the introduction of artificial light into a nest box, which is typically darker than the outside environment at night, may create a novel situation that disrupts sleep, rather than the alerting effects of light per se. 'Daylight' in laboratory studies is also

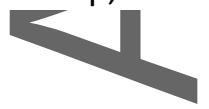

This article is protected by copyright. All rights reserved. 
typically much dimmer than natural sunlight, which is likely to have subsequent effects on sleep (Wams et al., 2017). On the other hand, field studies that measure the effects of real-life light at night are often correlational, and typically rely on behavioural proxies or questionnaires to measure sleep. The use of experimental protocols in real-world settings, together with more advanced techniques for measuring sleep (Aulsebrook et al., 2016), should help to address this major gap in our understanding.

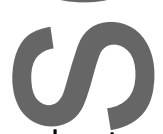

To better understand how ALAN affects sleep in wildlife, we also need to understand how diurnal animals behave in the presence of ALAN. Since ALAN is spatially heterogeneous, diurnal animals might actively avoid exposure to light at night by retreating to refugia (Dominoni, Carmona-Wagner, Hofmann, Kranstauber, \& Partecke, 2014, Longcore \& Rich, 2004). Avoidance behaviour could ameliorate some of the negative impacts on sleep, but at the cost of reduced habitat availability, increased competition, increased searching time for suitable sleeping sites, or the use of suboptimal sites. Conversely, if animals do not avoid light when sleeping, then they might face a greater risk of predation from visually-orienting predators. Animals might also be able to compensate for lost sleep by sleeping more deeply or sleeping during the day, as observed in migratory Swainson's thrushes (Catharus ustulatus; Fuchs, Haney, Jechura, Moore, \& Bingman, 2006) and white-crowned sparrows 335 (Zonotrichialeucophrys gambelii; Rattenborg et al., 2004). However, the thrushes and sparrows were wild-caught birds brought into a laboratory environment, such that it is unknown how they might respend to nocturnal sleep loss in the wild. Even if animals can compensate for nocturnal sleep loss, this behaviour could also lead to other costs, such as decreased foraging time and increased predation risk during the day (Lima et al., 2005).

This article is protected by copyright. All rights reserved. 
While we assume that impacts of ALAN on sleep are costly, there is currently little evidence to indicate the specific costs or their extent, or how (if present) they might be mitigated. Behavioural studies typically focus on sleep duration, but sleep intensity and composition might be equally important for fulfilling sleep functions (Joiner, 2016). Furthermore, if sleep requirements vary in wild animal populations, such that some individuals cope better with less sleep than others, then there could be scope for natural (or sexual) selection to favour reduced sleep need (Lesku et al., 2012). It is also unknown whether humans or animals can habituate to ALAN, allowing the impacts of ALAN on sleep to lessen over time. Given the known physiological pathways by which light at night affects melatonin, circadian rhythms, alertness, and sleep, complete habituation appears unlikely, yet the possibility is worthy of investigation. In humans, the impacts of ALAN might also increase over time, as our ability to work and socialise after sunset alters societal expectations (Jakle, 2001).

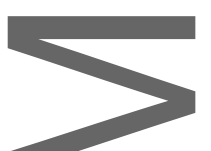

Importantly, current research also lacks taxonomic diversity, as most studies have been restricted to humans, laboratory rodents, and a few species of songbirds. ALAN can have major impacts on the behaviour and activity of diverse taxonomic groups, including insects (Knop et al., 2017), which suggests it could also have critical impacts on their sleep. Even closely related species or strains may respond differently to ALAN (Benca et al., 1998, also see Da Silva \& Kempenaers, 2017, Sun et al., 2017). Expanding the phylogenetic breadth of study species, and investigating how ecological factors may contribute to different responses, would provide a broader understanding of the costs of ALAN and lead to better management outcomes.

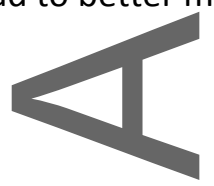

This article is protected by copyright. All rights reserved. 
From a practical perspective, further research is required to determine how to minimise any impacts of ALAN on sleep. The most obvious and effective solution would be to eliminate ALAN wherever it is not necessary. However, there are conflicting opinions about what is 'necessary', and many contexts -

where ALAN may have actual or perceived benefits for humans. In such contexts, mitigation is likely the best solution. Smarter lighting designs can reduce the penetration of light into unwanted or unnecessary areas, such as bedrooms and nature reserves (Gaston, Davies, Bennie, \& Hopkins, 2012). Since blue wavelengths of light have the greatest impact on melatonin and circadian rhythms, reducing or filtering out these wavelengths could also reduce impacts of ALAN on sleep. However, studies testing this approach for humans have reported mixed results (Ayaki et al., 2016, Heath et al., 2014, van der Lely et al., 2015), and little is known about whether it would benefit wildlife (Dimovski \& Robert, 2018). Other possible solutions include dimming lights or simply switching them off when they are of least benefit to humans (Davies \& Smyth 2018). The success of these solutions will depend on how sleep is affected by different timings, durations and intensities of light, for which further research is needed. In all likelihood, the best outcome will involve a combination of approaches, adapted for specific contexts. Importantly, while there are still some critical gaps in our understanding, there is sufficient evidence to warrant strategic minimisation of ALAN to reduce its harmful impacts

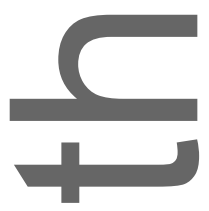

\section{Acknowledgements}

This article is protected by copyright. All rights reserved. 
We would like to thank Rowan Jacques-Hamilton for his valuable input into an earlier version of this manuscript.

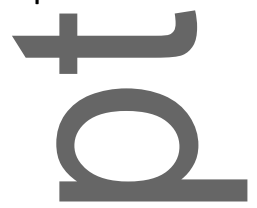

385
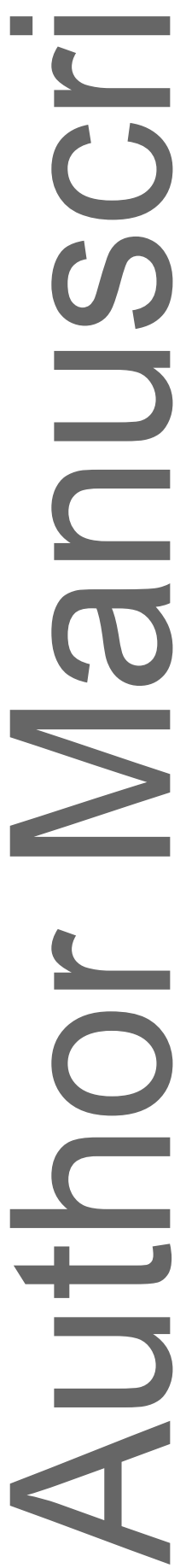

This article is protected by copyright. All rights reserved. 


\section{References}

Acerbi, A. \& Nunn, C. L. (2011). Predation and the phasing of sleep: an evolutionary individual-based model. Animal Behaviour, 81, 801-811. https://doi.org/10.1016/j.anbehav.2011.01.015

Alibhai, F. J., Tsimakouridze, E. V., Reitz, C. J., Pyle, W. G., \& Martino, T. A. (2015). Consequences of circadian and sleep disturbances for the cardiovascular system. Canadian Journal of Cardiology, 31, 860-872. https://doi.org/10.1016/j.cjca.2015.01.015

Altimus, C.M., Güler, A. D., Villa, K. L., McNeill, D. S., Legates, T. A., \& Hattar, S. (2008). Rods-cones and melanopsin detect light and dark to modulate sleep independent of image formation. Proceedings of the National Academy of Sciences of the United States of America, 105, 19998-20003. https://doi.org/10.1073/pnas.0808312105

Amlaner, C. J. \& Ball, N. J. (1983). A synthesis of sleep in wild birds. Behaviour, 87, 85-119. https://doi.org/10.1163/156853983x00138

Aschoff, J. (1965). Circadian rhythms in man. Science, 148, 1427-1432. https://doi.org/10.1007/9781-4899-6771-8_8

Aschoff, J. (1989). Temporal orientation - circadian clocks in animals and humans. Animal Behaviour, 37, 881-896. https://doi.org/10.1016/0003-3472(89)90132-2

Aulsebrook, A. E., Jones, T. M., Rattenborg, N. C., Roth, T. C., II, \& Lesku, J. A. (2016). Sleep ecophysiology: Integrating neuroscience and ecology. Trends in Ecology \& Evolution, 31, 590599.https://doi.org/10.1016/j.tree.2016.05.004

Axelrod, J., Wurtman, R. J., \& Snyder, S. H. (1965). Control of hydroxyindole O-methyltransferase activity in rat pineal gland by environmental lighting. Journal of Biological Chemistry, 240, 949-954.

Ayaki, M., Hattori, A., Maruyama, Y., Nakano, M., Yoshimura, M., Kitazawa, M., ... Tsubota, K. (2016). Protective effect of blue-light shield eyewear for adults against light pollution from self-luminous devices used at night. Chronobiology International, 33, 134-139. https://doi.org/10.3109/07420528.2015.1119158

Bakken, L. E. \& Bakken, G. S. (1977). American redstart feeding by artificial-light. Auk, 94, 373-374.

Beale, A. D., Pedrazzoli, M., Gonçalves, B. S. B., Beijamini, F., Duarte, N. E., Egan, K. J., . . Roden, L. C. (2017). Comparison between an African town and a neighbouring village shows delayed, but

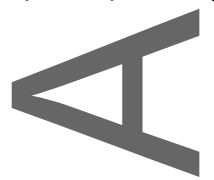

This article is protected by copyright. All rights reserved. 
not decreased, sleep during the early stages of urbanisation. Scientific Reports, 7, 5697. https://doi.org/10.1038/s41598-017-05712-3

Benca, R. M., Gilliland, M. A., \& Obermeyer, W. H. (1998). Effects of lighting conditions on sleep and wakefulness in albino Lewis and pigmented Brown Norway rats. Sleep, 21, 451-460. https://doj.org/10.1093/sleep/21.5.451

Berger, R. L. \& Phillips, N. H. (1994). Constant light suppresses sleep and circadian-rhythms in pigeons without consequent sleep rebound in darkness. American Journal of PhysiologyRegulatory/ntegrative and Comparative Physiology, 267, R945-R952.

Berson, D., Dunn, F. A., \& Takao, M. (2002). Phototransduction by retinal ganglion cells that set the circadian clock. Science, 295, 1070-1073. https://doi.org/10.1126/science.1067262

Borniger, J. C., Weil, Z. M., Zhang, N., \& Nelson, R. J. (2013). Dim light at night does not disrupt timing or quality of sleep in mice. Chronobiology International, 30, 1016-1023. https://doi.org/10.3109/07420528.2013.803196

Brüning, A., Hölker, F., Franke, S., Preuer, T., \& Kloas, W. (2015). Spotlight on fish: light pollution affects circadian rhythms of European perch but does not cause stress. Science of the Total Environment, 511, 516-522. https://doi.org/10.1016/j.scitotenv.2014.12.094

Burgess, H. J. \& Molina, T. A. (2014). Home lighting before usual bedtime impacts circadian timing: A field study. Photochemistry and Photobiology, 90, 723-726.

Cajochen, C., Zeitzer, J. M., Czeisler, C. A., \& Dijk, D. J. (2000). Dose-response relationship for light intensity and ocular and electroencephalographic correlates of human alertness. Behavioural Brain Research, 115, 75-83. https://doi.org/10.1016/s0166-4328(00)00236-9

Calisi, R. M \& Bentley, G. E. (2009). Lab and field experiments: are they the same animal? Hormones and Behaviour, 56, 1-10. https://doi.org/10.1016/j.yhbeh.2009.02.010

Carrier, J. \& Dumont, M. (1995). Sleep propensity and sleep architecture after bright light exposure at three different times of day. Journal of Sleep Research, 4, 202-211. https://doi.org/10.1111/j.1365-2869.1995.tb00171.x

Chang, A.-M., Aeschbach, D., Duffy, J. F., \& Czeisler, C. A. (2014). Evening use of light-emitting eReaders negatively affects sleep, circadian timing and next-morning alertness. PNAS, 112, 1232-1237. https://doi.org/10.1073/pnas.1418490112

Chang, A. M., Santhi, N., St Hilaire, M., Gronfier, C., Bradstreet, D. S., Duffy, J. F., . . Czeisler, C. A. (2012). Human responses to bright light of different durations. Journal of Physiology, 590, 3103-3112. https://doi.org/10.1113/jphysiol.2011.226555

This article is protected by copyright. All rights reserved. 
Chang, A. M., Scheer, F., \& Czeisler, C. A. (2011). The human circadian system adapts to prior photic history. Journal of Physiology, 589, 1095-1102. https://doi.org/10.1113/jphysiol.2010.201194

Chang, A. M., Scheer, F., Czeisler, C. A., \& Aeschbach, D. (2013). Direct effects of light on alertness, vigilance, and the waking electroencephalogram in humans depend on prior light history. Sleep, 36, 1239-1246. https://doi.org/10.5665/sleep.2894

Chellappa, S. L., Steiner, R., Oelhafen, P., Lang, D., Götz, T., Krebs, J., \& Cajochen, C. (2013). Acute exposure to evening blue-enriched light impacts on human sleep. Journal of Sleep Research, 22, 573-580. https://doi.org/10.1111/jsr.12050

Chen, S., Reichert, S., Singh, C., Oikonomou, G., Rihel, J., \& Prober, D. A. (2017). Light-dependent regulation of sleep and wake states by prokineticin 2 in zebrafish. Neuron, 95, 153-168 e156. https://doi.org/10.1016/j.neuron.2017.06.001

460 Chepesiuk, R. (2009). Missing the dark health effects of light pollution. Environmental Health Perspectives, 117, A20-A27. https://doi.org/10.1289/ehp.117-a20

Cho, C. H., Lee, H. J., Yoon, H. K., Kang, S. G., Bok, K. N., Jung, K. Y., . . Lee, E. I. (2016). Exposure to dim artificial light at night increases REM sleep and awakenings in humans. Chronobiology International, 33, 117-123. https://doi.org/10.3109/07420528.2015.1108980

465 Cho, J. R., Joo, E. Y., Koo, D. L., \& Hong, S. B. (2013). Let there be no light: the effect of bedside light on sleep quality and background electroencephalographic rhythms. Sleep Medicine, 14, 1422-1425. https://doi.org/10.1016/j.sleep.2013.09.007

Cho, Y., Ryu, S. H., Lee, B. R., Kim, K. H., Lee, E., \& Choi, J. (2015). Effects of artificial light at night on human health: A literature review of observational and experimental studies applied to exposure assessment. Chronobiology International, 32, 1294-1310. https://doi.org/10.3109/07420528.2015.1073158

Czeisler, C. (2013). Casting light on sleep deficiency. Nature, 497, S13-S13. https://doi.org/10.1038/497S13a

Czeisler, C. A., Allan, J. S., Strogatz, S. H., Ronda, J. M., Sánchez, R., Ríos, D. C., . . Kronauer, R. E. (1986). Bright light resets the human circadian pacemaker independent of the timing of the sleep-wake cycle. Science, 233, 667-671. https://doi.org/10.1126/science.3726555

Da Silva, A., de Jong, M., van Grunsven, R. H. A., Visser, M. E., Kempenaers, B., \& Spoelstra, K. (2017a). Experimental illumination of a forest: no effects of lights of different colours on the

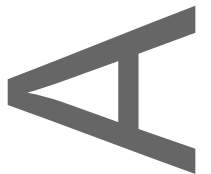

This article is protected by copyright. All rights reserved. 
onset of the dawn chorus in songbirds. R Soc Open Sci, 4, 160638.

Da Silva,A., Diez-Méndez, D., \& Kempenaers, B. (2017b). Effects of experimental night lighting on the daily timing of winter foraging in common European songbirds. Journal of Avian Biology, https://doj.org/10.1111/jav.01232]

Da Silva, A. \& Kempenaers, B. (2017). Singing from North to South: Latitudinal variation in timing of 485 dawn singing under natural and artificial light conditions. Journal of Animal Ecology, 86, 1286-1297. https://doi.org/10.1111/1365-2656.12739

Da Silva, A., Samplonius, J. M., Schlicht, E., Valcu, M., \& Kempenaers, B. (2014). Artificial night lighting rather than traffic noise affects the daily timing of dawn and dusk singing in common European songbirds. Behavioral Ecology, 25, 1037-1047. https://doi.org/10.1093/beheco/aru103

Da Silva, A., Valcu, M., \& Kempenaers, B. (2016). Behavioural plasticity in the onset of dawn song under intermittent experimental night lighting. Animal Behaviour, 117, 155-165. https://doi.org/10.1016/j.anbehav.2016.05.001

Davies, T. W. \& Smyth, T. (2018). Why artificial light at night should be a focus for global change 495 research in the 21st century. Global Change Biology, 24, 872-882. https://doi.org/10.1111/gcb.13927

Dawson, D. \& Reid, K. (1997). Fatigue, alcohol and performance impairment. Nature, 388, 235-235. https://doi.org/10.1038/40775

de Jong, M., Jeninga, L., Ouyang, J. Q., van Oers, K., Spoelstra, K., \& Visser, M. E. (2016). Dosedependent responses of avian daily rhythms to artificial light at night. Physiology \& Behaviour, 155, 172-179. https://doi.org/10.1016/j.physbeh.2015.12.012

de la Iglesia,H. O., Fernández-Duque, E., Golombek, D. A., Lanza, N., Duffy, J. F., Czeisler, C. A., \& Valeggia, C. R. (2015). Access to electric light is associated with shorter sleep duration in a traditionally hunter-gatherer community. Journal of Biological Rhythms, https://doi.org/10.1177/0748730415590702

DeCoursey, P. J., Walker, J. K., \& Smith, S. A. (2000). A circadian pacemaker in free-living chipmunks: essential for survival? Journal of Comparative Physiology a-Neuroethology Sensory Neural and Behavioral Physiology, 186, 169-180. https://doi.org/10.1007/s003590050017

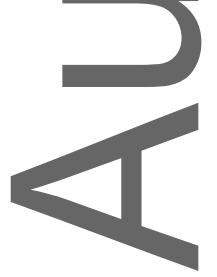

This article is protected by copyright. All rights reserved. 
Derégnaucourt, S., Mitra, P. P., Fehér, O., Pytte, C., \& Tchernichovski, O. (2005). How sleep affects the developmental learning of bird song. Nature, 433, 710-716. https://doi.org/10.1038/nature03275

Diekelmann, S. \& Born, J. (2010). The memory function of sleep. Nature Reviews: Neuroscience, 11, 114-126. https://doi.org/10.1038/nrn2762

Dijk, D. I. \& Archer, S. N. (2009). Light, sleep, and circadian rhythms: Together again. PLoS Biology, 7, e1000145. https://doi.org/10.1371/journal.pbio.1000145

Dimovski, A. M. \& Robert, K. A. (2018). Artificial light pollution: Shifting spectral wavelengths to mitigate physiological and health consequences in a nocturnal marsupial mammal. Journal of Experimental Zoology Part A: Ecological and Integrative Physiology, 1-9. https://doi.org/doi:10.1002/jez.2163

Dominoni, D. M., Borniger, J. C., \& Nelson, R. J. (2016). Light at night, clocks and health: from humans to wild organisms. Biology Letters, 12, 20160015. https://doi.org/10.1098/rsbl.2016.0015

Dominoni, D. M., Carmona-Wagner, E. O., Hofmann, M., Kranstauber, B., \& Partecke, J. (2014). Individual-based measurements of light intensity provide new insights into the effects of artificial light at night on daily rhythms of urban-dwelling songbirds. Journal of Animal Ecology 83, 681-692. https://doi.org/10.1111/1365-2656.12150

Dominoni, D. M., Goymann, W., Helm, B., \& Partecke, J. (2013a). Urban-like night illumination reduces melatonin release in European blackbirds (Turdus merula): implications of city life for biological time-keeping of songbirds. Frontiers in Zoology, 10, https://doi.org/10.1186/1742-9994-10-60

Dominoni, D. M., Helm, B., Lehmann, M., Dowse, H. B., \& Partecke, J. (2013b). Clocks for the city: circadian differences between forest and city songbirds. Proceedings of the Royal Society $B-$ Biological Sciences, 280, 20130593. https://doi.org/10.1098/rspb.2013.0593

Ekirch, A. R. (2001). Sleep we have lost: Pre-industrial slumber in the British Isles. American Historical Review, 106, 343-386. https://doi.org/10.2307/2651611

Ekirch, A. R. (2015). The modernization of western sleep: Or, does insomnia have a history? Past \& Present, 226, 149-192. https://doi.org/10.1093/pastj/gtu040

Ekirch, A. R. (2016). Segmented sleep in preindustrial societies. Sleep, 39, 715-716. https://doi.org/10.5665/sleep.5558

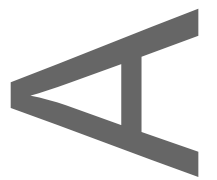

This article is protected by copyright. All rights reserved. 
Erren, T. C. \& Reiter, R. J. (2009). Light hygiene: Time to make preventive use of insights old and new into the nexus of the drug light, melatonin, clocks, chronodisruption and public health.

Medical Hypotheses, 73, 537-541. https://doi.org/10.1016/j.mehy.2009.06.003

Falchi, F., Cinzano, P., Duriscoe, D., Kyba, C. C. M., Elvidge, C. D., Baugh, K., . . Furgoni, R. (2016). The new world atlas of artificial night sky brightness. Science Advances, 2, https://doi.org/10.1126/sciadv.1600377

Fisher, S. P.,Foster, R. G., \& Peirson, S. N. (2013). The circadian control of sleep. Handbook of Experimental Pharmacology, 157-183. https://doi.org/10.1007/978-3-642-25950-0_7

Fuchs, T., Haney, A., Jechura, T. J., Moore, F. R., \& Bingman, V. P. (2006). Daytime naps in nightmigrating birds: behavioural adaptation to seasonal sleep deprivation in the Swainson's thrush, Catharus ustulatus. Animal Behaviour, 72, 951-958. https://doi.org/10.1016/j.anbehav.2006.03.008

Gandhi, A. V., Mosser, E. A., Oikonomou, G., \& Prober, D. A. (2015). Melatonin is required for the circadian regulation of sleep. Neuron, 85, 1193-1199. https://doi.org/10.1016/j.neuron.2015.02.016

Gaston, K. J., Davies, T. W., Bennie, J., \& Hopkins, J. (2012). Reducing the ecological consequences of night-time light pollution: options and developments. Journal of Applied Ecology, 49, 12561266. https://doi.org/10.1111/j.1365-2664.2012.02212.x

Gaston, K.J., Davies, T. W., Nedelec, S. L., \& Holt, L. A. (2017). Impacts of artificial light at night on biological timings. Annual Review of Ecology, Evolution, and Systematics, 48, 49-68. https://doi.org/10.1146/annurev-ecolsys-110316-022745

Gaston, K. J., Duffy, J. P., Gaston, S., Bennie, J., \& Davies, T. W. (2014). Human alteration of natural light cycles: causes and ecological consequences. Oecologia, 176, 917-931. https://doi.org/10.1007/s00442-014-3088-2

Gradisar, M., Wolfson, A. R., Harvey, A. G., Hale, L., Rosenberg, R., \& Czeisler, C. A. (2013). The sleep 565 and technology use of Americans: Findings from the National Sleep Foundation's 2011 Sleep in America poll. Journal of Clinical Sleep Medicine, 9, 1291-1299. https://doi.org/10.5664/jcsm.3272

Greives, T. J., Kingma, S. A., Kranstauber, B., Mortega, K., Wikelski, M., van Oers, K., . . Sockman, K. (2015). Costs of sleeping in: circadian rhythms influence cuckoldry risk in a songbird. Functional Ecology, n/a-n/a. https://doi.org/10.1111/1365-2435.12440

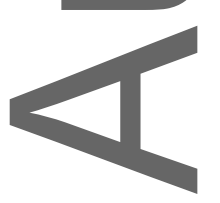

This article is protected by copyright. All rights reserved. 
Heath, M., Sutherland, C., Bartel, K., Gradisar, M., Williamson, P., Lovato, N., \& Micic, G. (2014). Does one hour of bright or short-wavelength filtered tablet screenlight have a meaningful effect on adolescents' pre-bedtime alertness, sleep, and daytime functioning? Chronobiology International, 31, 496-505. https://doi.org/10.3109/07420528.2013.872121

Horne, J. (2013). Why REM sleep? Clues beyond the laboratory in a more challenging world. Biological Psychology, 92, 152-168. https://doi.org/10.1016/j.biopsycho.2012.10.010

Huber, R., Ghilardi, M. F., Massimini, M., Ferrarelli, F., Riedner, B. A., Peterson, M. J., \& Tononi, G. (2006). Arm immobilization causes cortical plastic changes and locally decreases sleep slow wave activity. Nature Neuroscience, 9, 1169-1176. https://doi.org/10.1038/nn1758

Hysing, M., Pallesen, S., Stormark, K. M., Jakobsen, R., Lundervold, A. J., \& Sivertsen, B. (2015). Sleep and use of electronic devices in adolescence: Results from a large population-based study. BMsOpen, 5, e006748. https://doi.org/10.1136/bmjopen-2014-006748

Imeri, L. \& Opp, M. R. (2009). How (and why) the immune system makes us sleep. Nature Reviews Neuroscience, 10, 199-210. https://doi.org/10.1038/nrn2576

Jakle, J. A. (2001). City Lights: Illuminating the American Night. Baltimore: John Hopkins University Press. [in

Joiner, W. J. (2016). Unraveling the evolutionary determinants of sleep. Current Biology, 26, R1073R1087. https://doi.org/10.1016/j.cub.2016.08.068

Kasahara, T., Abe, K., Mekada, K., Yoshiki, A., \& Kato, T. (2010). Genetic variation of melatonin productivity in laboratory mice under domestication. Proceedings of the National Academy of Sciences of the United States of America, 107, 6412-6417. https://doi.org/10.1073/pnas.0914399107

Kayser, M. S., Yue, Z. F., \& Sehgal, A. (2014). A critical period of sleep for development of courtship circuitry and behavior in Drosophila. Science, 344, 269-274. https://doi.org/10.1126/science.1250553

Kempenaers, B., Borgstrom, P., Loës, P., Schlicht, E., \& Valcu, M. (2010). Artificial night lighting affects dawn song, extra-pair siring success, and lay date in songbirds. Current Biology, 20, 1735-1739. https://doi.org/10.1016/j.cub.2010.08.028

Knop, E., Zoller, L., Ryser, R., Gerpe, C., Horler, M., \& Fontaine, C. (2017). Artificial light at night as a 600 new threat to pollination. Nature, 548, 206-209. https://doi.org/10.1038/nature23288

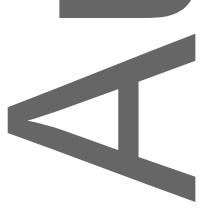

This article is protected by copyright. All rights reserved. 
Kronfeld-Schor, N. \& Dayan, T. (2003). Partitioning of time as an ecological resource. Annual Review of Ecology, Evolution, and Systematics, 34, 153-181. https://doi.org/10.1146/annurev.ecolsys.34.011802.132435

Kronfeld-Schor, N., Visser, M. E., Salis, L., \& van Gils, J. A. (2017). Chronobiology of interspecific 605 interactions in a changing world. Philosophical Transactions of the Royal Society of London Series B: Biological Sciences, 372, https://doi.org/10.1098/rstb.2016.0248

c.

Kyba, C. C. M., Kuester, T., Sánchez de Miguel, A., Baugh, K., Jechow, A., Hölker, F., ... Guanter, L. (2017). Artificially lit surface of Earth at night increasing in radiance and extent. Science Advances, 3, https://doi.org/10.1126/sciadv.1701528

610 Lesku, J. A., Meyer, L. C. R., Fuller, A., Maloney, S. K., Dell'Omo, G., Vyssotski, A. L., \& Rattenborg, N. C. (2011a). Ostriches sleep like platypuses. PloS One, 6, e23203. https://doi.org/10.1371/journal.pone.0023203

Lesku, J. A. \& Rattenborg, N. C. (2014). Avian sleep. Current Biology, 24, R12-14. https://doi.org/10.1016/j.cub.2013.10.005

615 Lesku, J. A., Rattenborg, N. C., Valcu, M., Vyssotski, A. L., Kuhn, S., Kuemmeth, F., ... Kempenaers, B. (2012). Adaptive sleep loss in polygynous pectoral sandpipers. Science, 337, 1654-1658. https://doi.org/10.1126/science.1220939

Lesku, J. A., Roth, T. C., Amlaner, C. J., \& Lima, S. L. (2006). A phylogenetic analysis of sleep architecture in mammals: the integration of anatomy, physiology, and ecology. American Naturalist, 168, 441-453. https://doi.org/10.1086/506973

Lesku, J. A., Roth, T C., Rattenborg, N. C., Amlaner, C. J., \& Lima, S. L. (2009). History and future of comparative analyses in sleep research. Neuroscience and Biobehavioral Reviews, 33, 10241036. https://doi.org/10.1016/j.neubiorev.2009.04.002

Lesku, J. A., Vyssotski, A. L., Martinez-Gonzalez, D., Wilzeck, C., \& Rattenborg, N. C. (2011b). Local sleep homeostasis in the avian brain: convergence of sleep function in mammals and birds? Proceedings of the Royal Society B-Biological Sciences, 278, 2419-2428. https://doi.org/10.1098/rspb.2010.2316

Lima, S. L., Rattenborg, N. C., Lesku, J. A., \& Amlaner, C. J. (2005). Sleeping under the risk of predation. Animal Behaviour, 70, 723-736. https://doi.org/10.1016/j.anbehav.2005.01.008

630 Longcore, T. \& Rich, C. (2004). Ecological light pollution. Frontiers in Ecology and the Environment, 2, 191-198. https://doi.org/10.2307/3868314

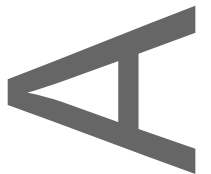

This article is protected by copyright. All rights reserved. 
Marino, M., Li, Y., Rueschman, M. N., Winkelman, J. W., Ellenbogen, J. M., Solet, J. M., . . Buxton, O. M. (2013). Measuring sleep: accuracy, sensitivity, and specificity of wrist actigraphy compared to polysomnography. Sleep, 36, 1747-1755. https://doi.org/10.5665/sleep.3142

Martinez-Gonzalez, D., Lesku, J. A., \& Rattenborg, N. C. (2008). Increased EEG spectral power density during sleep following short-term sleep deprivation in pigeons (Columba livia): evidence for avian sleep homeostasis. Journal of Sleep Research, 17, 140-153.

https://doilorg/10.1111/j.1365-2869.2008.00636.x

Martino, T.A., Oudit, G. Y., Herzenberg, A. M., Tata, N., Koletar, M. M., Kabir, G. M., . . Sole, M. J.

(2008). Circadian rhythm disorganization produces profound cardiovascular and renal disease in hamsters. American Journal of Physiology: Regulatory, Integrative and Comparative Physiology, 294, R1675-1683. https://doi.org/10.1152/ajpregu.00829.2007

Nath, R. D., Bedbrook, C. N., Abrams, M. J., Basinger, T., Bois, J. S., Prober, D. A., . . Goentoro, L. (2017). The jellyfish Cassiopea exhibits a sleep-like state. Current Biology, 27, 2984-+. https://doi.org/10.1016/j.cub.2017.08.014

Navara, K. J. \& Nelson, R. J. (2007). The dark side of light at night: physiological, epidemiological, and ecological consequences. Journal of Pineal Research, 43, 215-224. https://doi.org/10.1111/j.1600-079X.2007.00473.x

Nordt, A. \& Klenke, R. (2013). Sleepless in town - drivers of the temporal shift in dawn song in urban 650 European blackbirds. PloS One, 8, e71476. https://doi.org/10.1371/journal.pone.0071476

Ohayon, M. M. \& Milesi, C. (2016). Artificial outdoor nighttime lights associate with altered sleep behavior in the American general population. Sleep, 39, 1311-1320. https://doi.org/10.5665/sleep.5860

Omond, S., ky, L. M. T., Beaton, R., Storm, J. J., Hale, M. W., \& Lesku, J. A. (2017). Inactivity is nycthemeral, endogenously generated, homeostatically regulated, and melatonin modulated in a free-living platyhelminth flatworm. Sleep, 40, https://doi.org/10.1093/sleep/zsx124

Ouyang, J. O., de Jong, M., van Grunsven, R. H. A., Matson, K. D., Haussmann, M. F., Meerlo, P., . . Spoelstra, K. (2017). Restless roosts: Light pollution affects behavior, sleep, and physiology in a free-living songbird. Global Change Biology, https://doi.org/10.1111/gcb.13756

Panda, S., Hogenesch, J. B., \& Kay, S. A. (2002). Circadian rhythms from flies to human. Nature, 417, 329-335. https://doi.org/10.1038/417329a

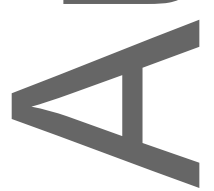

This article is protected by copyright. All rights reserved. 
Paquet, J., Kawinska, A., \& Carrier, J. (2007). Wake detection capacity of actigraphy during sleep. Sleep, 30, 1362-1369. https://doi.org/10.1093/sleep/30.10.1362

Pauley, S. M. (2004). Lighting for the human circadian clock: recent research indicates that lighting has become a public health issue. Medical Hypotheses, 63, 588-596.

https://doj.org/10.1016/j.mehy.2004.03.020

Peixoto, C.A. T., da Silva, A. G. T., Carskadon, M. A., \& Louzada, F. M. (2009). Adolescents living in homes without electric lighting have earlier sleep times. Behavioral Sleep Medicine, 7, 73-80. https://doi.org/10.1080/15402000902762311

Phillips, D. J., Savenkova, M. I., \& Karatsoreos, I. N. (2015). Environmental disruption of the circadian clock leads to altered sleep and immune responses in mouse. Brain Behavior and Immunity, 47, 14-23. https://doi.org/10.1016/j.bbi.2014.12.008

Phillips, N. H. \& Berger, R. J. (1992). Melatonin infusions restore sleep suppressed by continuous bright light in pigeons. Neuroscience Letters, 145, 217-220. https://doi.org/10.1016/03043940(92)90026-4

Raap, T., Pinxten, R., \& Eens, M. (2015). Light pollution disrupts sleep in free-living animals. Scientific Reports, 5, 13557. https://doi.org/10.1038/srep13557

Raap, T., Pinxten, R., \& Eens, M. (2016). Artificial light at night disrupts sleep in female great tits 680 (Parus major) during the nestling period, and is followed by a sleep rebound. Environmental Pollution, 215, 125-134. https://doi.org/10.1016/j.envpol.2016.04.100

Raap, T., Pinxten, R., \& Eens, M. (2017). Rigorous field experiments are essential to understand the genuine severity of light pollution and to identify possible solutions. Global Change Biology, https://doi.org/10.1111/gcb.13843

Raap, T., Pinxten, R, \& Eens, M. (2018). Artificial light at night causes an unexpected increase in oxalate in developing male songbirds. Conservation Physiology, 6, coy005. https://doj.org/10.1093/conphys/coy005

Raap, T., Sun, J., Pinxten, R., \& Eens, M. (2017). Disruptive effects of light pollution on sleep in freeliving birds: Season and/or light intensity-dependent? Behavioural Processes, 144, 13-19. https://doi.org/10.1016/j.beproc.2017.08.011

Randler, C. (2014). Sleep, sleep timing and chronotype in animal behaviour. Animal Behaviour, 94, 161-166. https://doi.org/10.1016/j.anbehav.2014.05.001

Rångtell, F. H., Ekstrand, E., Rapp, L., Lagermalm, A., Liethof, L., Búcaro, M. O., . . Benedict, C. (2016). Two hours of evening reading on a self-luminous tablet vs. reading a physical book

This article is protected by copyright. All rights reserved. 
does not alter sleep after daytime bright light exposure. Sleep Medicine, 23, 111-118. https://doi.org/10.1016/j.sleep.2016.06.016

Rattenborg, N. C., de la Iglesia, H. O., Kempenaers, B., Lesku, J. A., Meerlo, P., \& Scriba, M. F. (2017). Sleep research goes wild: new methods and approaches to investigate the ecology, evolution and functions of sleep. Philosophical Transactions of the Royal Society B-Biological Sciences, 372, https://doi.org/10.1098/rstb.2016.0251

Rattenborg, N. C., Mandt, B. H., Obermeyer, W. H., Winsauer, P. J., Huber, R., Wikelski, M., \& Benca, R. M. (2004). Migratory sleeplessness in the white-crowned sparrow (Zonotrichia leucophrys gambelii). PLoS Biology, 2, E212. https://doi.org/10.1371/journal.pbio.0020212

Rattenborg, N. C., Obermeyer, W. H., Vacha, E., \& Benca, R. M. (2005). Acute effects of light and darkness on sleep in the pigeon (Columba livia). Physiology \& Behaviour, 84, 635-640. https://doi.org/10.1016/j.physbeh.2005.02.009

Rattenborg, N. C., Voirin, B., Cruz, S. M., Tisdale, R., Dell'Omo, G., Lipp, H. P., . . Vyssotski, A. L. (2016). Evidence that birds sleep in mid-flight. Nature Communications, 7, 12468. https://doi.org/10.1038/ncomms12468

Rattenborg, N. C., Voirin, B., Vyssotski, A. L., Kays, R. W., Spoelstra, K., Kuemmeth, F., . . Wikelski, M. (2008). Sleeping outside the box: electroencephalographic measures of sleep in sloths inhabiting a rainforest. Biology Letters, 4, 402-405. https://doi.org/10.1098/rsbl.2008.0203

Reiter, R. J., Tan, D.X., \& Fuentes-Broto, L. (2010). Melatonin: a multitasking molecule. Progress in Brain Research, 181, 127-151. https://doi.org/10.1016/s0079-6123(08)81008-4

Robert, K. A., Lesku, J. A., Partecke, J., \& Chambers, B. (2015). Artificial light at night desynchronises strictly seasonal reproduction in a wild mammal. Proceedings of the Royal Society $B$ Bialogical Sciences, 282, 20151745. https://doi.org/10.1098/rspb.2015.1745

Roth, T. C., Rattenborg, N. C., \& Pravosudov, V. V. (2010). The ecological relevance of sleep: the trade-off between sleep, memory and energy conservation. Philosophical Transactions of the Royal Society B-Biological Sciences, 365, 945-959. https://doi.org/10.1098/rstb.2009.0209

Russ, A., Rüger, A., \& Klenke, R. (2014). Seize the night: European blackbirds (Turdus merula) extend their foraging activity under artificial illumination. Journal of Ornithology, 156, 123-131. https://doi.org/10.1007/s10336-014-1105-1

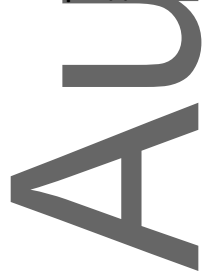

This article is protected by copyright. All rights reserved. 
Samson, D. R., Crittenden, A. N., Mabulla, I. A., Mabulla, A. Z., \& Nunn, C. L. (2017a). Hadza sleep biology: Evidence for flexible sleep-wake patterns in hunter-gatherers. American Journal of Physical Anthropology, https://doi.org/10.1002/ajpa.23160

Samson, D. R., Manus, M. B., Krystal, A. D., Fakir, E., Yu, J. J., \& Nunn, C. L. (2017b). Segmented sleep in a nonelectric, small-scale agricultural society in Madagascar. American Journal of Human Biology, 29, https://doi.org/10.1002/ajhb.22979

Santhi, N., Thorne, H. C., van der Veen, D. R., Johnsen, S., Mills, S. L., Hommes, V., . . Dijk, D. J. (2012). The spectral composition of evening light and individual differences in the suppression of melatonin and delay of sleep in humans. Journal of Pineal Research, 53, 4759. https://doi.org/10.1111/j.1600-079X.2011.00970.x Effects of artificial illumination on the nocturnal foraging of waders. Acta Oecologica, 36, 166-172. https://doi.org/10.1016/j.actao.2009.11.008

Schmidt, M. H. (2014). The energy allocation function of sleep: a unifying theory of sleep, torpor, and continuous wakefulness. Neuroscience and Biobehavioral Reviews, 47, 122-153. https://doi.org/10.1016/j.neubiorev.2014.08.001

Schmidt, M.H., Swang, T. W., Hamilton, I. M., \& Best, J. A. (2017). State-dependent metabolic partitioning and energy conservation: A theoretical framework for understanding the function of sleep. PloS One, 12, e0185746. https://doi.org/10.1371/journal.pone.0185746

Scriba, M. F., Ducrest, A. L., Henry, I., Vyssotski, A. L., Rattenborg, N. C., \& Roulin, A. (2013). Linking melanism to brain development: expression of a melanism-related gene in barn owl feather follicles covaries with sleep ontogeny. Frontiers in Zoology, 10, https://doi.org/10.1186/1742-9994-10-42

Spoelstra, K., Verhagen, I., Meijer, D., \& Visser, M. E. (2018). Artificial light at night shifts daily activity patterns but not the internal clock in the great tit (Parus major). Proceedings: Biological Sciences, 285, https://doi.org/10.1098/rspb.2017.2751

Steinmeyer, C., Schielzeth, H., Mueller, J. C., \& Kempenaers, B. (2010). Variation in sleep behaviour in free-living blue tits, Cyanistes caeruleus: effects of sex, age and environment. Animal Behaviour,-80, 853-864. https://doi.org/10.1016/j.anbehav.2010.08.005

Stenvers, D. J., van Dorp, R., Foppen, E., Mendoza, J., Opperhuizen, A. L., Fliers, E., . . Deboer, T. (2016). Dim light at night disturbs the daily sleep-wake cycle in the rat. Scientific Reports, 6 , 35662. https://doi.org/10.1038/srep35662

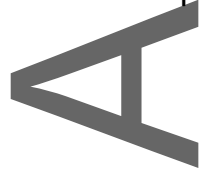

This article is protected by copyright. All rights reserved. 
Stephenson, R., Lim, J., Famina, S., Caron, A. M., \& Dowse, H. B. (2012). Sleep-wake behavior in the rat: ultradian rhythms in a light-dark cycle and continuous bright light. Journal of Biological Rhythms, 27, 490-501. https://doi.org/10.1177/0748730412461247

Stevens, R. G., Blask, D. E., Brainard, G. C., Hansen, J., Lockley, S. W., Provencio, I., . . Reinlib, L. (2007). Meeting report: The role of environmental lighting and circadian disruption in cancer and other diseases. Environmental Health Perspectives, 115, 1357-1362.

https://doilorg/10.1289/ehp.10200

Stevens, R.G. \& Zhu, Y. (2015). Electric light, particularly at night, disrupts human circadian

rhythmicity: is that a problem? Philosophical Transactions of the Royal Society B-Biological Sciences, 370, 20140120. https://doi.org/10.1098/rstb.2014.0120

Stracey, C. M., Wynn, B., \& Robinson, S. K. (2014). Light pollution allows the northern mockingbird (Mimus polyglottos) to feed nestlings after dark. The Wilson Journal of Ornithology, 126, 366-369. https://doi.org/10.1676/13-107.1

Stuber, E. F., Baumgartner, C., Dingemanse, N. J., Kempenaers, B., \& Mueller, J. C. (2016). Genetic correlates of individual differences in sleep behavior of free-living great tits (Parus major). G3 (Bethesda), 6, 599-607. https://doi.org/10.1534/g3.115.024216

Sun, J., Raap, T., Pinxten, R., \& Eens, M. (2017). Artificial light at night affects sleep behaviour differently in two closely related songbird species. Environmental Pollution, 231, 882-889. https://doi.org/10.1016/j.envpol.2017.08.098

Tan, D. X., Hardeland, R., Manchester, L. C., Paredes, S. D., Korkmaz, A., Sainz, R. M., . . Reiter, R. J. (2010). The changing biological roles of melatonin during evolution: from an antioxidant to signals of darkness, sexual selection and fitness. Biological Reviews, 85, 607-623. https://doi.org/10.1111/j.1469-185X.2009.00118.x

Tobler, I. (2011). Phylogeny of sleep regulation. In: Kryger MH, Roth T, Dement WC, editors.

Principles and Practice of Sleep Medicine, Fifth Edition: Elsevier Health Sciences. p 112-125.

Tobler, I., Franken, P., Alföldi, P., \& Borbély, A. A. (1994). Room light impairs sleep in the albino rat. Behavioural Brain Research, 63, 205-211. https://doi.org/10.1016/0166-4328(94)90092-2

van derLely, S., Frey, S., Garbazza, C., Wirz-Justice, A., Jenni, O. G., Steiner, R., . . Schmidt, C. (2015). Blue blocker glasses as a countermeasure for alerting effects of evening light-emitting diode screen exposure in male teenagers. Journal of Adolescent Health, 56, 113-119. https://doi.org/10.1016/j.jadohealth.2014.08.002

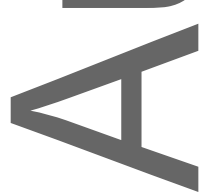

This article is protected by copyright. All rights reserved. 
Van Dongen, H. P. A., Maislin, G., Mullington, J. M., \& Dinges, D. F. (2003). The cumulative cost of additional wakefulness: dose-response effects on neurobehavioral functions and sleep physiology from chronic sleep restriction and total sleep deprivation. Sleep, 26, 117-126. https://doi.org/10.1093/sleep/26.2.117

Voirin, B., Scriba, M. F., Martinez-Gonzalez, D., Vyssotski, A. L., Wikelski, M., \& Rattenborg, N. C. (2014). Ecology and neurophysiology of sleep in two wild sloth species. Sleep, 37, 753-761. https://doilorg/10.5665/sleep.3584

Vyazovskiy, V. V.\&Delogu, A. (2014). NREM and REM Sleep: complementary roles in recovery after wakefulness. Neuroscientist, 20, 203-219. https://doi.org/10.1177/1073858413518152

Vyssotski, A. L., Dell'Omo, G., Dell'Ariccia, G., Abramchuk, A. N., Serkov, A. N., Latanov, A. V., . . Lipp, H. P. (2009). EEG responses to visual landmarks in flying pigeons. Current Biology, 19, 11591166. https://doi.org/10.1016/j.cub.2009.05.070

800 Wams, E. J., Woelders, T., Marring, I., van Rosmalen, L., Beersma, D. G. M., Gordijn, M. C. M., \& Hut, R. A. (2017). Linking light exposure and subsequent sleep: A field polysomnography study in humans. Sleep, 40, https://doi.org/10.1093/sleep/zsx165

Wehr, T. A. (1992). In short photoperiods, human sleep is biphasic. Journal of Sleep Research, 1, 103107.https:/doi.org/10.1111/j.1365-2869.1992.tb00019.x

805 Weljie, A. M., Meerlo, P., Goel, N., Sengupta, A., Kayser, M. S., Abel, T., . . Sehgal, A. (2015). Oxalic acid and diacylglycerol 36:3 are cross-species markers of sleep debt. PNAS, 112, 2569-2574. https://doi.org/10.1073/pnas.1417432112

Westerlund, A., Lagerros, Y. T., Kecklund, G., Axelsson, J., \& Akerstedt, T. (2016). Relationships between questionnaire ratings of sleep quality and polysomnography in healthy adults. Behavioural Sleep Medicine, 14, 185-199. https://doi.org/10.1080/15402002.2014.974181

Winnebeck, E. C., Fischer, D., Leise, T., \& Roenneberg, T. (2017). Dynamics and ultradian structure of human sleep in real life. Current Biology, https://doi.org/10.1016/j.cub.2017.11.063

Wright, K. P, McHill, A. W., Birks, B. R., Griffin, B. R., Rusterholz, T., \& Chinoy, E. D. (2013). Entrainment of the human circadian clock to the natural light-dark cycle. Current Biology, 23, 1554-1558. https://doi.org/10.1016/j.cub.2013.06.039

Xie, L. L., Kang, H. Y., Xu, Q. W., Chen, M. J., Liao, Y. H., Thiyagarajan, M., . . Nedergaard, M. (2013). Sleep drives metabolite clearance from the adult brain. Science, 342, 373-377. https://doi.org/10.1126/science.1241224

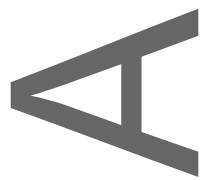

This article is protected by copyright. All rights reserved. 
Yadav, A., Verma, P., \& Singh, S. (2017). Going beyond the limits: effect of clock disruption on human health. Biological Rhythm Research, 48, 693-700. https://doi.org/10.1080/09291016.2017.1345428

Yetish, G., Kaplan, H., Gurven, M., Wood, B., Pontzer, H., Manger, P. R., . . Siegel, J. M. (2015). Natural sleep and its seasonal variations in three pre-industrial societies. Current Biology, 25, 2862-2868. https://doi.org/10.1016/j.cub.2015.09.046

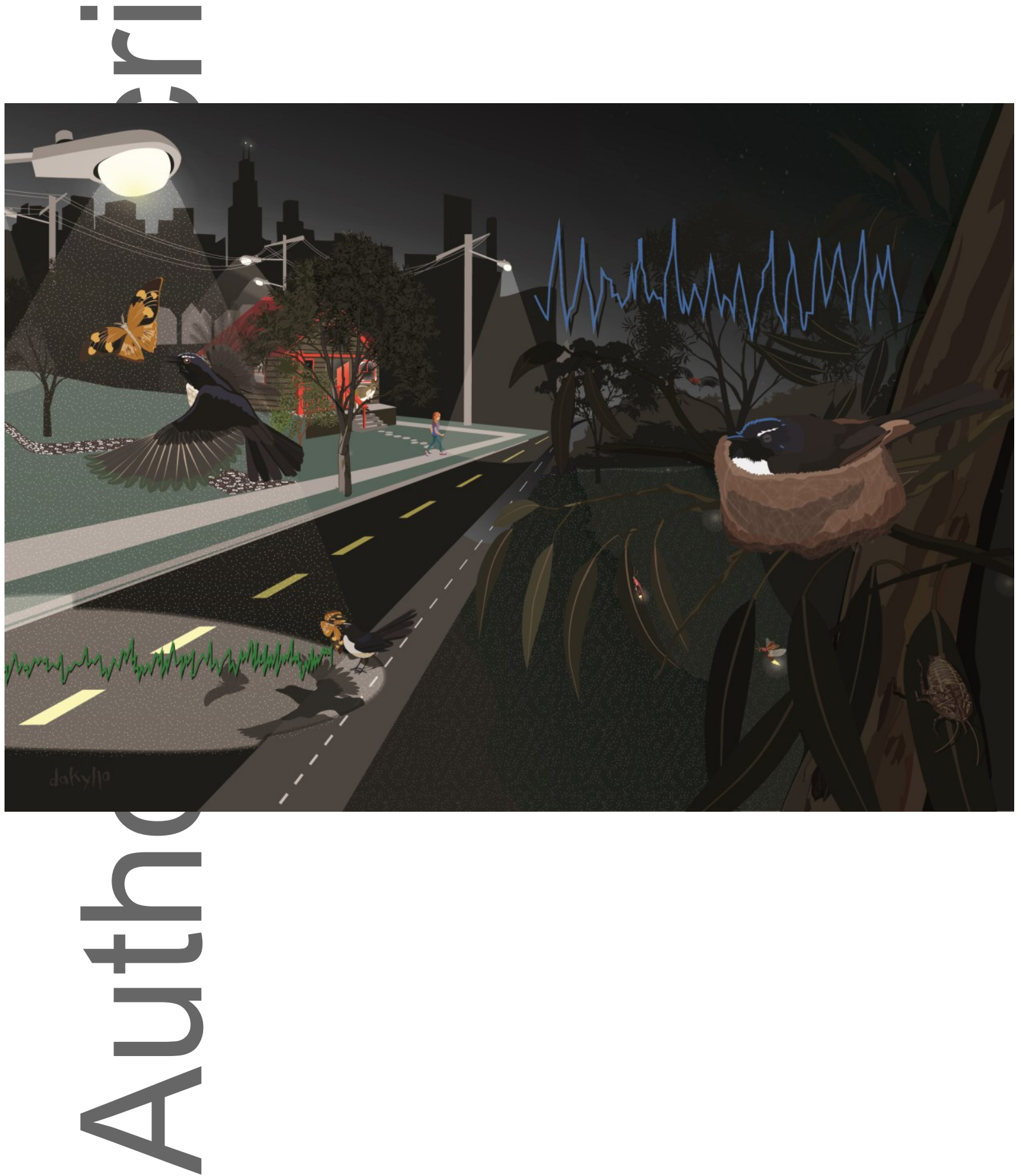

This article is protected by copyright. All rights reserved. 

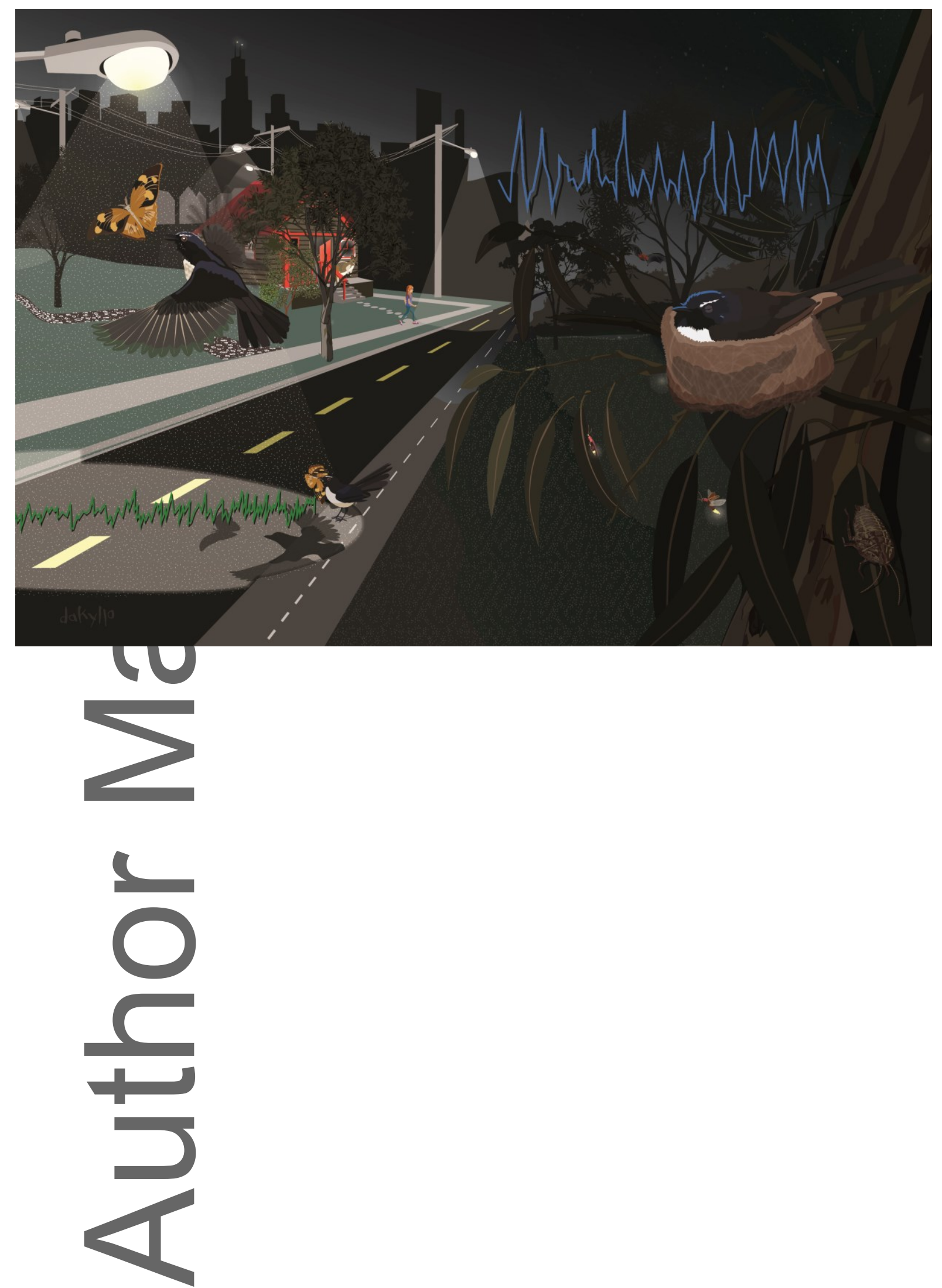

This article is protected by copyright. All rights reserved. 


\section{University Library}

\section{- M M N E R VA A gateway to Melbourne's research publications}

Minerva Access is the Institutional Repository of The University of Melbourne

Author/s:

Aulsebrook, AE;Jones, TM;Mulder, RA;Lesku, JA

Title:

Impacts of artificial light at night on sleep: A review and prospectus

Date:

2018-10-01

Citation:

Aulsebrook, A. E., Jones, T. M., Mulder, R. A. \& Lesku, J. A. (2018). Impacts of artificial light at night on sleep: A review and prospectus. JOURNAL OF EXPERIMENTAL ZOOLOGY PART A-ECOLOGICAL AND INTEGRATIVE PHYSIOLOGY, 329 (8-9), pp.409-418. https:// doi.org/10.1002/jez.2189.

Persistent Link:

http://hdl.handle.net/11343/284035 